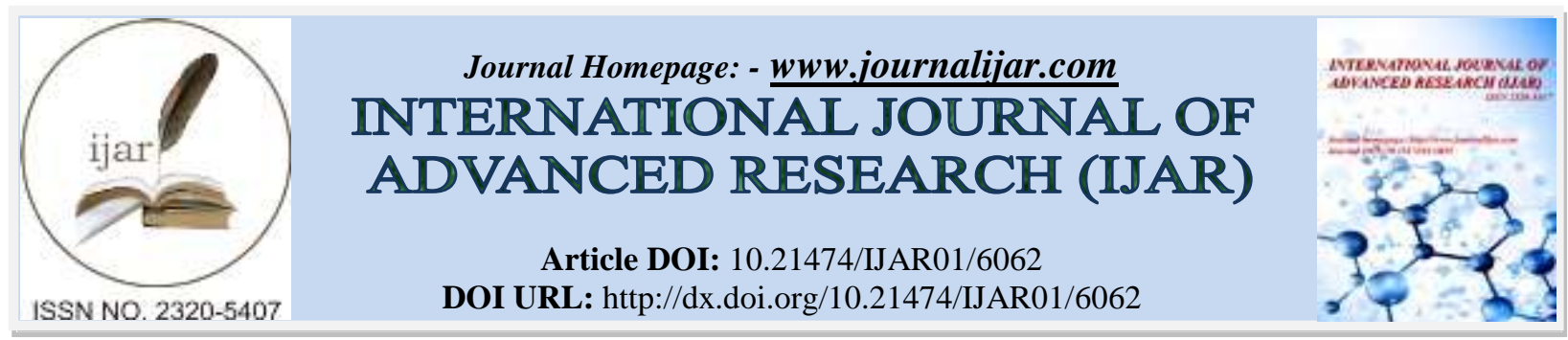

RESEARCH ARTICLE

\title{
TNF- $\alpha$ GENE (308G/A) PROMOTER REGION POLYMORPHISM IN METABOLIC SYNDROME: A PILOT STUDY IN NORTH INDIA.
}

\section{Dr. Sandhya Lal MD ${ }^{1}$, Dr. Rajni Dawar $\mathrm{MD}^{2}$, Dr. M. K. Bhatnagar $\mathrm{MD}^{3}$ and Dr. Jayashree Bhattacharjee $\mathrm{MD}^{4}$.}

1. Attending Consultant, Biochemistry, Lab Medicine, Jaypee Healthcare, Noida, Uttar Pradesh, India.

2. Associate Professor, Biochemistry, VMMC, New Delhi, India.

3. Professor, Medicine, LHMC \& SSKH, New Delhi, India.

4. Director Professor, Biochemistry, LHMC \& SSKH, New Delhi, India.

\section{Manuscript Info Abstract}

Received: 14 October 2017

Final Accepted: 16 November 2017

Published: December 2017

\section{Key words:-}

TNF- $\alpha$, Metabolic Syndrome,

Polymorphism, Genetic Predisposition.
Introduction: Metabolic Syndrome is attracting a lot of scientific and commercial interest as the factors defining the syndrome are all associated with increased morbidity and mortality in general and there is still lot of controversy in definitions as well as pathophysiology due to multifactorial etiology. Inflammation and genetic factors play important role along with other factors.

Aim: To study the association of TNF- $\alpha$ gene (308G/A) promoter region polymorphism with metabolic syndrome and to study inter genotypic variation of TNF $\alpha$ levels in cases and controls

Materials and Methods: A total of 93 subjects (46 Cases \& 47 Controls) were enrolled into the study with informed consent. All subjects were above 25 years of age \& cases had metabolic syndrome diagnosed according to IDF 2006 criteria (for Asian population) while controls were age- and sex-matched healthy subjects not fitting into IDF 2006 criteria. TNF- $\alpha$ levels were estimated by Sandwich ELISA and promoter region polymorphism was studied by DNA extraction followed by Polymerase Chain Reaction and Restriction fragment Length Polymorphism.

Results: TNF- $\alpha$ level among cases $(16.48 \pm 6.68 \mathrm{pg} / \mathrm{mL})$ was significantly higher than controls $(1.90 \pm 0.80 \mathrm{pg} / \mathrm{mL})$. In cases, GG genotype was found in $63 \%$ (29); GA in 33\% (15), followed by AA in $4 \%$ (2). Among controls GG genotype was present in $85 \%$ (40) and GA in $15 \%$ (7) and no subject had AA genotype. The genotype distribution was in Hardy Weinberg Equilibrium $\left(\chi^{2}=6.653, \mathrm{df}=2, \mathrm{p}<0.05\right)$. The difference was found statistically significant $(\mathrm{p}<0.001)$. Allelic Frequency difference between the two groups was also significant $(\mathrm{p}<$ $0.05)$. Intergenotypic variations in the levels of TNF- $\alpha$ came significantly different $(\mathrm{p}<0.05)$ by ANOVA and T Test

Conclusion: We conclude that inflammation is involved in etiopathogenesis of MetS and GA and AA genotype is associated with increased transcription of TNF- $\alpha$ suggesting their regulation at genetic level. 
Copy Right, IJAR, 2017,. All rights reserved.

\section{Introduction:-}

The metabolic syndrome (MetS) is a cluster of interrelated risk factors of metabolic origin including abdominal obesity, atherogenic dyslipidemia, elevated blood pressure, elevated plasma glucose level, and prothrombotic and proinflammatory states that promote development of atherosclerotic CVD and type 2 diabetes mellitus(T2DM) [1]. MetS has reached epidemic proportions worldwide. The prevalence of obesity and metabolic syndrome is rapidly increasing in India and other South Asian countries, leading to increased mortality and morbidity due to CVD and T2DM. [2.3] Approximately about one third of urban South Asians have evidence of the metabolic syndrome.[4] The etiology of the metabolic syndrome is complex, determined by the interplay of both genetic and environmental factors. Pathways leading to the clinical manifestations of the metabolic syndrome involve a number of metabolic risk factors, as well as mediators of the inflammatory response [5]

Tumour necrosis factor-alpha (TNF- $\alpha)$ is a pro inflammatory cytokine released by inflammatory leucocytes as well as vascular endothelial and smooth muscle cells. It plays a key role in orchestrating the complex events involved in inflammation and immunity. It is also a key cytokine in the inflammation process of atherosclerosis. Through its effects on lipid metabolism, insulin resistance and endothelial function, it might be involved in coronary heart disease (CHD) [6]

TNF- $\alpha$ gene is located in the chromosomal region 6p21.1-21.3, next to the major histocompatibility complex, coding for a 157-amino acid polypeptide processed from a 233-amino acid precursor [6]. A biallelic polymorphism within the promoter region of TNF- $\alpha$ locus at the position -308 has been reported to be associated with TNF- $\alpha$ production. A G/A substitution at position -308 upstream from the transcription initiation site in the promoter region of the gene have been identified [7]. In vitro experiments have demonstrated that this DNA NcoI restriction fragment length polymorphism increases transcriptional activation of the TNF- $\alpha$ gene [8]. Although controversial, the majority of the data support a direct role for this biallelic polymorphism in the elevated TNF- $\alpha$ levels observed in homozygotes for the -308 A allele [9]. Some, but not all studies have indicated a key role for the 308G/A variant of the TNF- $\alpha$ gene in the pathogenesis of various components of the metabolic syndrome and insulin resistance [10, 11].

So, this study was aimed at finding association if any between TNF- $\alpha$ gene (308G/A) promoter region variant (polymorphism) in the cases of metabolic syndrome and the controls, in north Indian population and the effect of this polymorphism on levels of TNF $\alpha$.

\section{Material and Methods:-}

The study was carried out in the department of Biochemistry in collaboration with the department of Medicine, Lady Harding Medical College and Smt. Sucheta Kriplani Hospital, New Delhi. The study group consisted of 93 subjects with informed consent. Case group had 46 patients of both the sex and above 25 years of age with Metabolic Syndrome according to IDF 2006(12) (for Asian population). Exclusion criteria for cases was, history of any acute inflammatory disease in past 2 month, any history of ongoing chronic inflammatory pathology (including patients of TB on treatment, rheumatoid arthritis. systemic lupus erythromatosus, pelvic inflammatory disease, inflammatory bowel disease, connective tissue disorders), any history of chronic lung disease (COPD), chronic liver disease (Cirrhosis), chronic renal disease, any type of debilitating illness (cancer). Control group consisted of 47 age- and sex-matched healthy controls.

Detailed clinical history with special reference to metabolic syndrome risk factors was taken. Estimation of TNF- $\alpha$ level in all subjects was done by commercial Sandwich ELISA kit (DIACLONE). Study of TNF- $\alpha 308 \mathrm{G} / \mathrm{A}$ promoter region gene polymorphism was done by extracting DNA from whole blood followed by PCR, and RFLP. The DNA Extraction was done using Himedia HiPurAtm Blood Genomic DNA Miniprep Purification Kit for whole blood. In extracted DNA, concentration was ascertained by spectrophotometric measurement of optical density at $260 \mathrm{~nm}$. The amount of DNA was quantified by using relation $1 \mathrm{OD}$ at $260 \mathrm{~nm}=50 \mathrm{ng} / \mu \mathrm{l}$. Purity of DNA was ascertained by calculating A260/A280 ratio. The ratio for pure DNA was in range of 1.5-1.8. The extracted genomic DNA was amplified by PCR using flanking polymorphic region of TNF- $\alpha$ gene. Primer pair used was as follows: Forward Primer: 5'-AGGCAATAGGTTTTGAGGGGCAT-3' (23bp) and Reverse Primer: 'TCCTCCCTGCTCCGATTCCG-3' (20bp) 
PCR assay targeting TNF- $\alpha$ Gene was done in a total volume of $50 \mu$ l of reaction mixture. Preparation of reaction mixture was done taking all necessary precaution to avoid any contamination. Reaction cocktail was prepared using: $30 \mu \mathrm{l}$ PCR master mix $+10 \mu \mathrm{l}$ DNA sample $+5 \mu$ l Forward Primer $+5 \mu$ l Reverse Primer. Mixed properly by vortex gently and then centrifuging. [PCR Master Mix (In-Vitrogen): $22 \mathrm{U} / \mathrm{ml}$ Taq DNA polymerase, Taq Antibody, $22 \mathrm{mM}$ Tris-HCl$(\mathrm{pH} 8.4), 55 \mathrm{mM} \mathrm{KCl}, 1.65 \mathrm{mM} \mathrm{MgCl} 2,220 \mu \mathrm{M}$ of each dGTP ,dATP, dTTP , dCTP, Stabilizers].

PCR programme used in thermocycler : Initial Denaturation at $94^{\circ} \mathrm{C}$ X $3 \mathrm{~min}$, Cycle Denaturation at $94^{\circ} \mathrm{C}$ X 1 min, Cycle Annealing at $66^{\circ} \mathrm{C} \mathrm{X} 1 \mathrm{~min}$, Cycle Extension at $72^{\circ} \mathrm{C} \mathrm{X} 1 \mathrm{~min}$ and Final Extension at $72^{\circ} \mathrm{C} \mathrm{X} 5 \mathrm{~min}$. PCR products along with $50 \mathrm{bp}$ DNA ladder were electrophoresed on $2 \%$ agarose gel to confirm the presence of the products (Figure 1) The resulting PCR product $(10 \mu \mathrm{l})$ was digested with 5 units of NcoI restriction enzyme at $37{ }^{\circ} \mathrm{C}$ overnight and electrophoresed on $2 \%$ agarose gel. NcoI-RFLP was detected by ethidium bromide staining which revealed a two-allele polymorphism that produced three bands of different sizes: a set of 87 and 20 bp corresponding to the presence of the restriction site which is wild type (G-allele) and 107-bp fragment corresponding to the absence of restriction site which is a mutant type(A-allele) (Figure 2). The identified genotypes were named accordingly, GG for homozygous wild, GA for heterozygous and AA for homozygous mutant.

Statistical Analysis: All the analysis for the clinical and laboratory data was performed with the SPSS version 19 software programme. Values were expressed as percentage, mean, and standard error of mean. Frequencies of Genotype were compared with chi-square tests and Fischer's exact test. A $p$-value of $<0.05$ was considered as significant.

\section{Results:-}

The mean TNF- $\alpha$ level among cases is $16.48 \pm 6.68 \mathrm{pg} / \mathrm{mL}$ and among controls is $1.90 \pm 0.80 \mathrm{pg} / \mathrm{mL}$ with statistically significant $(\mathrm{p}<0.05)$ difference between two groups as shown in Table I.

Table-I:- Plasma TNF- $\alpha$ levels among cases $(\mathrm{N}=46)$ and controls $(\mathrm{N}=47)$

\begin{tabular}{|c|c|c|c|c|c|}
\hline \multicolumn{6}{|c|}{ GROUPS } \\
\hline \multirow{3}{*}{ TNF- $\alpha(\mathbf{p g} / \mathbf{m L})$} & \multicolumn{2}{|c|}{ CASES (N=46) } & CONTROLS (N=47) & \\
\cline { 2 - 6 } & Mean & S.E.M & Mean & S.E.M & P Value \\
\cline { 2 - 6 } & 16.48 & 6.68 & 1.90 & 0.80 & $\mathbf{0 . 0 3 1}^{*}$ \\
\hline
\end{tabular}

$* \mathrm{p}<0.05$ : significant.

For genotypic distribution, GG genotype was found in 29 subjects (63\%) among cases and in 40 subjects (85\%) among controls. GA genotype was found in 15 subjects (33\%) among cases and in 7 subjects (15\%) among controls. AA genotype was found in 2 subjects (4\%) among cases only and none among controls. The genotype distribution is in Hardy Weinberg Equilibrium $\left(\chi^{2}=6.653\right.$, df $=2, p<0.05$, Significant). The frequency of $\mathrm{G}$ allele was in $80 \%$ among cases and $92 \%$ among controls. The frequency of A allele was in $20 \%$ among cases and $8 \%$ among controls. Allelic difference between the two groups is significant $(\mathrm{p}<0.05)$ as shown in Table II.

Table-II:- Distribution of genotypes and alleles of TNF- $\alpha$ among cases $(\mathrm{N}=46)$ and controls $(\mathrm{N}=47)$

\begin{tabular}{|c|c|c|c|c|c|}
\hline \multirow[t]{2}{*}{ Genotye } & \multicolumn{2}{|c|}{$\begin{array}{l}\text { CASES } \\
(\mathrm{N}=46)\end{array}$} & \multicolumn{2}{|c|}{$\begin{array}{l}\text { CONTROLS } \\
(\mathrm{N}=47)\end{array}$} & \multirow[t]{2}{*}{ Level of Significance } \\
\hline & $\mathbf{N}$ & Frequency $(\%)$ & $\mathbf{N}$ & Frequency (\%) & \\
\hline GG & 29 & $63 \%$ & 40 & $85 \%$ & $\begin{array}{l}\text { Pearson } \chi=6.653 \\
\mathbf{p}=\mathbf{0 . 0 3 6}(\mathbf{d f}=\mathbf{2})\end{array}$ \\
\hline GA/AA & 17 & $37 \%$ & 7 & $15 \%$ & $\begin{array}{c}\mathrm{LR}=7.500 \\
\mathbf{p}=\mathbf{0 . 0 2 4}\end{array}$ \\
\hline \multicolumn{6}{|l|}{ Alleles } \\
\hline $\mathbf{G}$ & 74 & $80 \%$ & 87 & $92 \%$ & \multirow[t]{2}{*}{$\mathbf{p}=0.009 * *$} \\
\hline $\mathbf{A}$ & 18 & $20 \%$ & 7 & $8 \%$ & \\
\hline
\end{tabular}

** $\mathrm{P}<0.01$ : Highly significant. 
Figure 1:- Ethidium Bromide Stained Gel Picture of PCR Product (107bp)

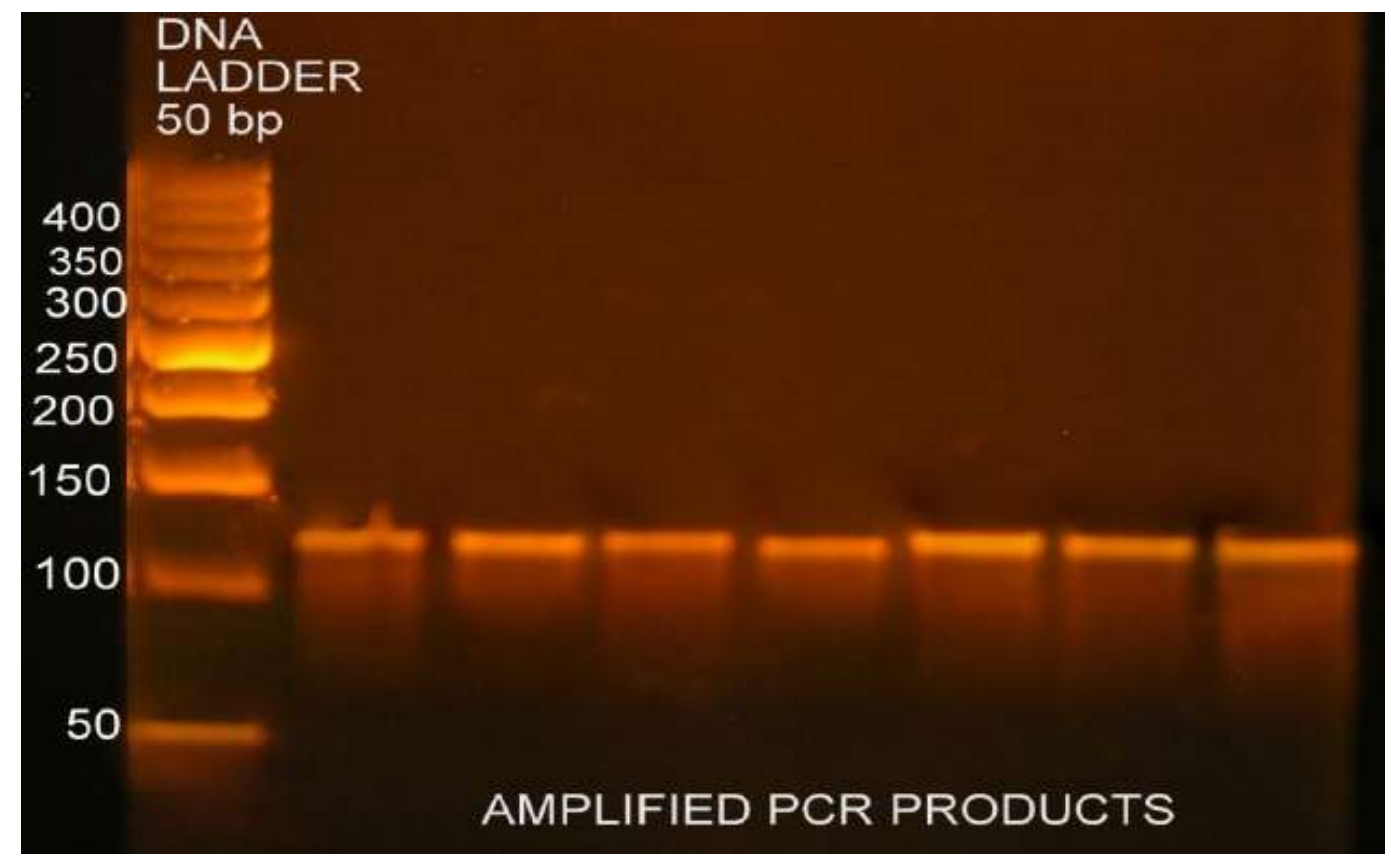

Figure 2:- Ethidium bromide-stained Agarose gel showing Nco1 digested PCR products (RFLP) with primers

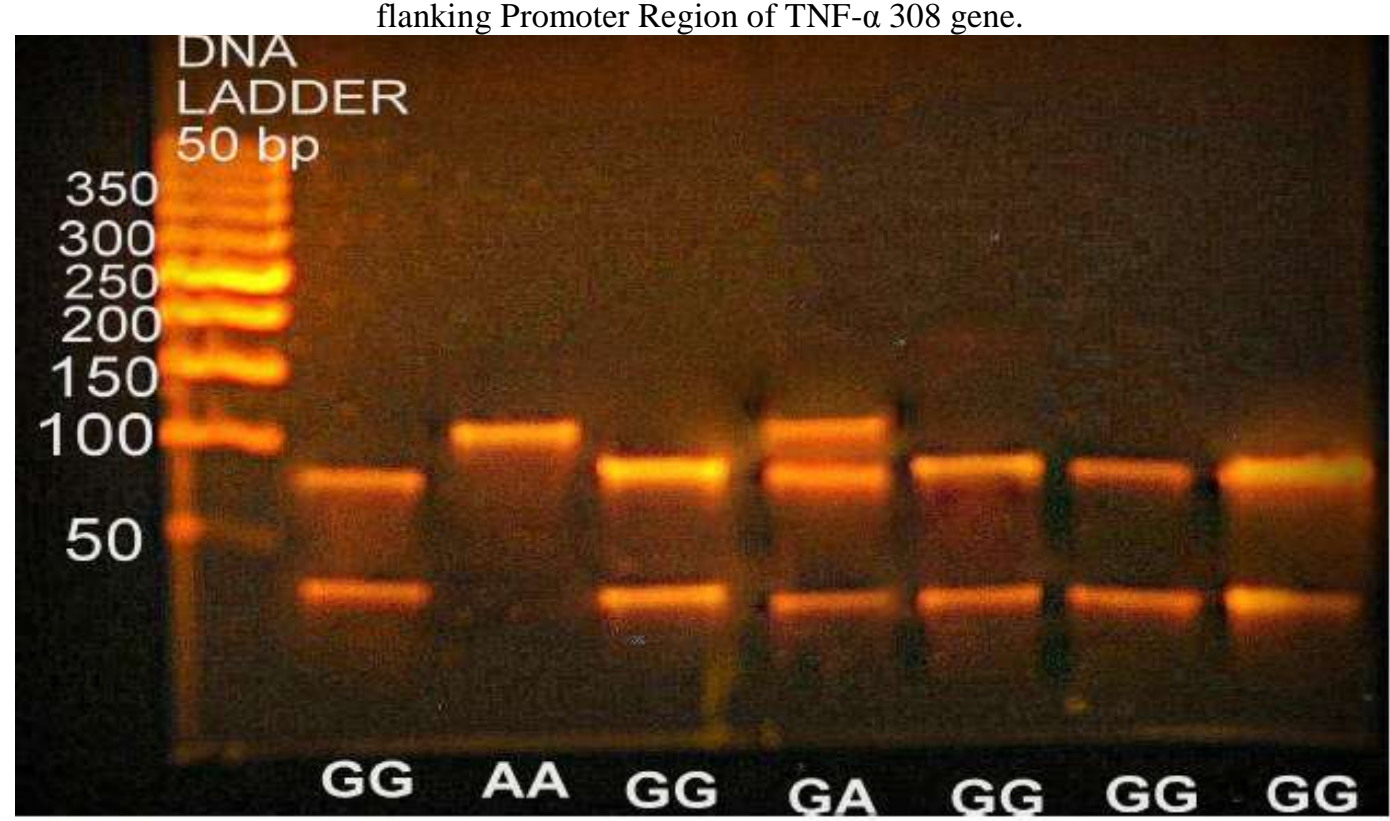

The mean plasma TNF- $\alpha$ level of GG genotype among cases is $0.448 \pm 0.256 \mathrm{pg} / \mathrm{mL}$ while among controls is $0.563 \pm 0.464 \mathrm{pg} / \mathrm{mL}$. The mean plasma TNF- $\alpha$ level of GA genotype among cases is $25.133 \pm 9.819 \mathrm{pg} / \mathrm{mL} \mathrm{while}$ among controls is $9.571 \pm 3.657 \mathrm{pg} / \mathrm{mL}$. The mean plasma TNF- $\alpha$ level of AA genotype among cases is $184.0 \pm 61.0$ $\mathrm{pg} / \mathrm{mL}$ while among controls there was no AA genotype. Intergenotypic variation of plasma TNF- $\alpha$ level among cases is highly significant $(\mathrm{p}<0.001)$ as illustrated by ANOVA analysis. Intergenotypic variation of plasma TNF- $\alpha$ level among controls is highly significant $(\mathrm{p}<0.001)$ T-TEST as graphically represented in Figure 3. 
Figure 3:- Intergenotypic variation of plasma TNF- $\alpha$ level among cases $(\mathrm{N}=46)$ and controls $(\mathrm{N}=47)$

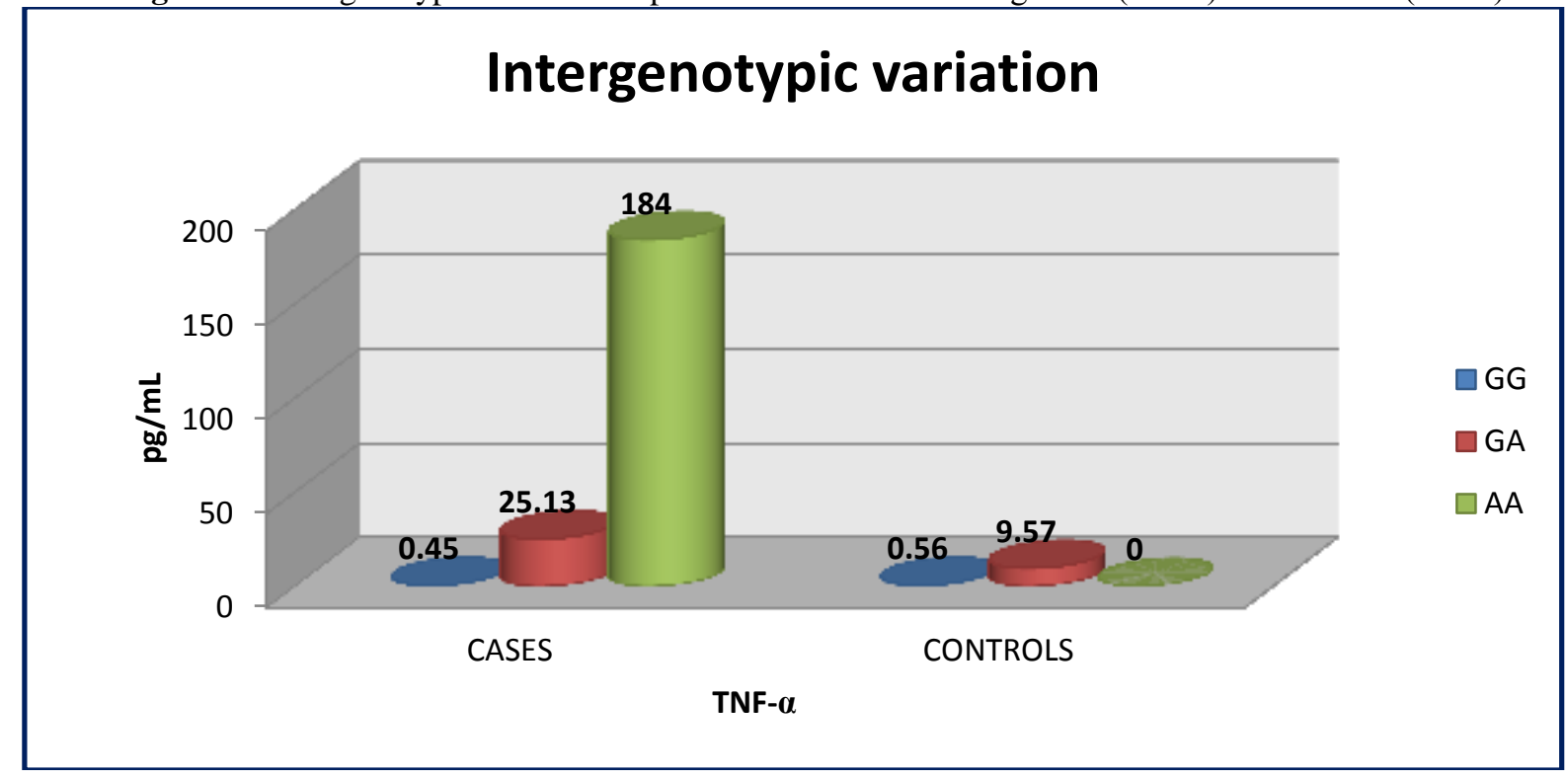

\section{Discussion:-}

In present study 97 subjects were included out of which 46 were diagnosed cases of metabolic syndrome (IDF 2006 criteria for MetS) [12] including both the sexes and 47 age- and sex-matched healthy controls were taken. The mean age of cases was $50.30 \pm 1.37$ years and for controls it is $49.04 \pm 0.73$. The study population consisted of $74 \%$ Females and 26\% Males. The study population included majority of females as Lady Hardinge medical college and Smt. Sucheta kriplani hospital where this study was done has a very high input of female patients because of old reputation of high quality services and patient care in obstetrics and gynaecology. According to history taken $76 \%$ of females were post-menopausal. There are studies showing increased prevalence of metabolic syndrome in postmenopausal women [13].

We found that mean TNF- $\alpha$ level among cases is $16.48 \pm 6.68 \mathrm{pg} / \mathrm{mL}$ and among controls is $1.90 \pm 0.80 \mathrm{pg} / \mathrm{mL}$ with statistically significant $(\mathrm{p}<0.05)$ difference between the two groups. TNF is a pro-inflammatory cytokine secreted by monocyte, macrophages and endothelial cells, and also to a large extent by adipocytes. Several studies have shown that levels of TNF- $\alpha$ are an important regulator of insulin sensitivity which is known to be impaired in metabolic syndrome. [14] In human subjects, TNF- $\alpha$ messenger RNA (mRNA) and protein positively correlate with body adiposity and decrease in obese subjects with weight loss. [15]

The first demonstration that TNF- $\alpha$ may be relevant to metabolic diseases associated with over-nutrition (such as obesity-related T2D) was made by Hotamisligil and colleagues, who showed that TNF- $\alpha$ is elevated in adipose tissue from obese diabetic rodents and is a mediator of obesity-related insulin resistance and T2D [16]. Significantly higher levels of TNF- $\alpha$ in MetS cases also suggest that inflammation has major role in the etiopathogenesis of the same.

In our study GG genotype was found in 29 subjects (63\%) among cases and in 40 subjects (85\%) among controls. GA genotype was found in 15 subjects (33\%) among cases and in 7 subjects (15\%) among controls. AA genotype was found in 2 subjects (4\%) among cases only and none among controls. The genotype distribution was in Hardy Weinberg Equilibrium $\left(\chi^{2}=6.653, \mathrm{df}=2, \mathrm{p}<0.05\right.$, Significant $)$. The difference was found significant $(\mathrm{p}<0.05)$. The frequency of $\mathrm{G}$ allele was in $80 \%$ among cases and $92 \%$ among controls. The frequency of A allele was in $20 \%$ among cases and $8 \%$ among controls. Allelic difference between the two groups is significant $(\mathrm{p}<0.05)$.

The TNF- $\alpha$ 308G/A polymorphism in the promoter of the TNF- $\alpha$ gene has been studied extensively in several populations with conflicting results. [17] The TNF- $\alpha$ 308A variant, which is associated with human leukocyte antigens A1, B8, and DR3 alleles, is a much more powerful transcription activator, compared with the TNF- $\alpha$ 308G of allele, explaining the increased TNF- $\alpha$ production found in these individuals [18]. Based on these previous studies 
and because the rate transcription is an important regulator of TNF- $\alpha$ expression, genetic variation within regulatory regions of the TNF- $\alpha$ gene could contribute to altered expression of the cytokine in adipose cells. Our study also shows a significant association of TNF- $\alpha$ level with mutant (A) allele of TNF- $\alpha$ 308G/A polymorphism. The association of variants in the promoter of the TNF- $\alpha$ gene with obesity and insulin resistance is controversial, and there have been both negative and positive[19] reports for these associations over the last years.

Not many studies have been done in India regarding 308G/A TNF- $\alpha$ polymorphism in the promoter region in metabolic syndrome cases. A study with similar result in agreement to our study was carried out by Vani Gupta et al. They found distribution of GG, GA, AA genotypes in cases $62.3 \%, 33.83 \%, 3.34 \%$ respectively and allelic frequency of $\mathrm{G}$ and $\mathrm{A}$ allele were $79.74 \%$ and $20.26 \%$ respectively among cases. [20] Also their study showed that homozygous mutant genotype (AA) $(\mathrm{p}=<0.001$ : $\mathrm{OR}=3.24$ : $95 \% \mathrm{CI}=2.15-4.89)$ and mutant allele $(\mathrm{A})(\mathrm{p}=$ <0.001: $\mathrm{OR}=3.04: 95 \% \mathrm{CI}=2.08-4.43)$ of $\mathrm{TNF}-\alpha$ was significantly less frequently observed in the control population as compared to study group similar to the findings in our study. [20]

The mean plasma TNF- $\alpha$ level of GG genotype among cases was $0.448 \pm 0.256 \mathrm{pg} / \mathrm{mL}$ while among controls was $0.563 \pm 0.464 \mathrm{pg} / \mathrm{mL}$. The mean plasma TNF- $\alpha$ level of GA genotype among cases was $25.133 \pm 9.819 \mathrm{pg} / \mathrm{mL}$ while among controls was $9.571 \pm 3.657 \mathrm{pg} / \mathrm{mL}$. The mean plasma TNF- $\alpha$ level of AA genotype among cases was $184.0 \pm 61.0 \mathrm{pg} / \mathrm{mL}$ while among controls none of the subjects had AA genotype. The difference between the groups as analysed by ANOVA and T-test was statistically significant $(\mathrm{p}<0.05)$. These findings suggest GA and AA genotype is associated with increased transcription of TNF- $\alpha$ involved in the inflammatory process in MetS.

So, we can say that TNF- $\alpha$ promoter region gene 308G/A polymorphism by affecting TNF- $\alpha$ levels may be associated with Metabolic Syndrome. TNF- $\alpha$ levels and its promoter region polymorphism may prove to be helpful in risk assessment for early diagnosis of Metabolic Syndrome so that appropriate interventional measures can be taken at right time to prevent its future complications: the Type 2DM and CVD, for which it serves as the early predictor.

The findings of the present study are a small step put forward. Further studies are necessary to confirm, evaluate and replicate this study in a larger sample size with different ethnicities

\section{Conclusion:-}

Our study supports the view that inflammation is involved in the etiopathogenesis of MetS .We also found that inflammatory markers are being regulated at genetic level. Mutated genotype (TNF- $\alpha$ 308G/A) which leads to increased transcription of the pro-inflammatory marker TNF- $\alpha$ is thereby involved in the pathogenesis of MetS and its future complication.

Our study limitation was small sample size. So we recommend that similar study should be conducted in various parts of the world with different ethnicities and environmental conditions including more number of subjects. This is because etiology of the metabolic syndrome is complex, determined by the interplay of both genetic and environmental factors. Understanding the links between the components of the metabolic syndrome, proinflammatory markers, endothelial dysfunction, along with the genes involved will enable physicians and scientists to approach the phenotypic problems (hypertension, diabetes, dyslipidemia, obesity) in a more rational and mechanism-based manner.

\section{References:-}

1. Spinler SA. Challenges associated with metabolic syndrome. Pharmacotherapy 2006 Dec; 26(12, 2): 209S217S.

2. Mohan V, Rao GHR. Type 2 Diabetes in South Asains. 1st ed. New Delhi: South Asian Society on Atherosclerosis and Thrombosis; 2007.

3. Prasad DS, Kabir Z, Dash AK, Das BC. Abdominal obesity, an independent cardiovascular risk factor in Indian subcontinent: A clinico epidemiological evidence summary. J Cardiovasc Dis Res 2011; 2:199-205.

4. Misra A, Khurana L. The metabolic syndrome in South Asians: Epidemiology, clinical correlates and possible solutions. International Diabetes Monitor 2009; 21:92-101.

5. Sonnenberg, G. E., Krakower G.R., Kissebah AH. A novel pathway to the manifestation of metabolic syndrome. Obes Res. 2004 12: 180-186. 
6. Vendrell J, Fernandez-Real JM, Gutierrez C, Zamora A, Simon I, Bardaji A, et al. A Polymorphism in the promoter of the tumour necrosis factor alpha gene (-308) is associated with coronary heart disease in type 2 diabetic patients. Atherosclerosis 2003 April; 167(2): 257-64.

7. Wilson AG, di Giovine FS, Blakemore AI, Duff GW. Single base polymorphism in the human tumour necrosis factor a (TNF-a) gene detectable by NcoI restriction of PCR product. Hum Mol Genet 1992; 1: 353.

8. Aguillón JC, Cruzat A, Aravena O, Salazar L, Llanos C, Cuchacovich M. Could single-nucleotide polymorphisms (SNPs) affecting the tumour necrosis factor promoter be considered as part of rheumatoid arthritis evolution? Immunobiology 2006; 211(1-2): 75-84.

9. Abraham LJ, Kroeger KM. Impact of the $2308 \mathrm{TNF}$ promoter polymorphism on the transcriptional regulation of the TNF gene: relevance to disease. J Leukocyte Biol 1999; 66: 562-6.

10. Sookoian S, García SI, Gianotti TF, Dieuzeide G, González CD, Pirola CJ, et al. The G-308A promoter variant of the tumour necrosis factor-alpha gene is associated with hypertension in adolescents harbouring the metabolic syndrome. Am J Hypertens 2005; 18(10): 1271-5.

11. Fernandez-Real JM, Gutierrez C, Ricart W, Casamitjana R, Fernandez-Castaner M, Vendrell J, et al. The TNF-a gene NCO I polymorphism influences the relationship among insulin resistance, percent body fat and increased serum leptin levels. Diabetes 1997; 46: 1468-71.

12. Alberti KG, Zimmet P, Shaw J. The metabolic syndrome - a new worldwide definition. IDF Epidemiology Task Force Consensus Group. Lancet 2005; 366: 1059-1062.

13. You Tongjian, Alice S. Ryan S. Alice, Nicklas J. Barbara. The Metabolic Syndrome in Obese Postmenopausal Women: Relationship to Body Composition, Visceral Fat, and Inflammation. The Journal of Clinical Endocrinology \& Metabolism 2004 November 1; 89 (11): 5517-5522.

14. Chakraborty S, Zawieja S, Wang W, Zawieja DC, Muthuchamy M. Lymphatic system: A vital link between metabolic syndrome and inflammation. Ann. N.Y. Acad. Sci.2010; S1: E94-E102.

15. William P. Cawthorn, Jaswinder K. Sethi. TNF-a and adipocyte biology. FEBS Letters 2008; 582: 117-131.

16. Hotamisligil GS. Inflammation and metabolic disorders.Nature.2006; 444: 860-867.

17. Elva Perez-Luque, Juan Manuel Malacara, Ma. Eugenia Garay-Sevilla, Martha Eugenia Fajardo. Association of the TNF- $\alpha-308 \mathrm{G} / \mathrm{A}$ polymorphism with family history of type 2 diabetes mellitus in a Mexican population. Clinical Biochemistry 2012 January; 45(1-2): 12-15.

18. Abraham LJ, Kroeger KM. Impact of the $308 \mathrm{TNF}$ promoter polymorphism on the transcriptional regulation of the TNF gene: relevance to disease. J Leukocyte Biol 1999; 66: 562-6.

19. Sookoian SC, González C, Pirola CJ. Meta-analysis on the G-308A tumour necrosis factor alpha gene variant and phenotypes associated with the metabolic syndrome. Obes Res 2005; 13(12): 2122-31.

20. Gupta Vani, Gupta Abhishek, Jafar Tabrez, Gupta Vandana, Agrawal Suraksha, Srivastava Nidhi, et al. Association of TNF-a promoter gene G-308A polymorphism with metabolic syndrome, insulin resistance, serum TNF-a and leptin levels in Indian adult women Cytokine 2012; 57: 32-36. 